\title{
Effects of Lime Application on Activities of Related Enzymes and Protein Expression of Saponin Metabolism of Panax notoginseng under Cadmium Stress
}

\author{
Zuran $\mathrm{Li}^{1}$, Yueqin Jiang ${ }^{2}$, Yanqun $\mathrm{Zu}^{2 *}$, Xinyue Mei ${ }^{2 * *}$, Li Qin ${ }^{2}$, Bo $\mathrm{Li}^{2}$ \\ ${ }^{1}$ College of Horticulture and Landscape, Yunnan Agriculture University, P.R. China \\ ${ }^{2}$ College of Resources and Environment, Yunnan Agriculture University, P.R. China
}

Received: 7 February 2020

Accepted: 14 April 2020

\begin{abstract}
Panax notoginseng was used as material with exogenous $\mathrm{Cd}\left(0,0.6,3.0,6.0,9.0,12 \mathrm{mg} \mathrm{kg}^{-1}\right.$, prepared with $\left.\mathrm{CdCl}_{2}\right)$ and lime $\left(0,0.75,1.5 \mathrm{tha}^{-2}\right.$, prepared with $\left.\mathrm{Ca}(\mathrm{OH})_{2}\right)$ application to study the effect of cadmium stress on growth and saponins contents of $P$. notoginseng, the relative enzymes activities of saponins metabolism (SS, mevalonate kinase(MVK), $\mathrm{P} 450, \beta$-amyrin synthase ( $\beta$-AS)) and protein expression used with iTRAQ proteome analysis technique to understand the response mechanism of P. notoginseng. The results showed the contents of soil available $\mathrm{Cd}$ and $\mathrm{Cd}$ contents in main root decreased under lime application. The available contents of soil $\mathrm{Cd}$ decreased by $9.2 \%-38.1 \%$ with $1.5 \mathrm{t} \mathrm{ha}^{-2}$ lime application under $\mathrm{Cd}$ treatments. The biomass, root length, root surface area and root volume increased with lime application under $\mathrm{Cd}$ stress. The activities and expression levels of MVK, P450 and $\beta$-amyrin synthase decreased, resulting in decrease $8.6 \%-23.6 \%$ in saponins contents and ratio of Rg1 to Rb1. In general, the results indicate excessive application of lime would lead to a certain reduction in the content of saponin under $\mathrm{Cd}$ stress and inhibition of conversion of diol-saponins to triol-saponins with single-peak model to $\mathrm{Ca} / \mathrm{Cd}$ ratio. It could be recommended that the ratio of $\mathrm{Ca}$ to $\mathrm{Cd}$ is less than 680 for reduction of cadmium content and maintaining saponin contents of main root of P. notoginseng for the production of high quality.
\end{abstract}

Keywords: Panax notoginseng, lime, metabolism, heavy metal, iTRAQ proteome analysis

\section{Introduction}

The soil Cd pollution has become one of the most important environmental problems [1]. Due to a series

*e-mail: 649332092@qq.com

**e-mail: 339257631@qq.com of activities of humans, including irrigation of farmland sewage and industrial wastes, the contents of heavy metals in the soil increased [2-4]. Cadmium in soil could be absorbed by plants, which affects plant growth and physiological metabolism and reduces the yield and quality of crops [5,6]. Plants reduce the toxic effects of heavy metals by altering their own structure 
or secondary metabolic pathways $[7,8]$. Protein change mechanism and protein-protein interactions could be studied through proteome technology. Isobaric tags for relative and absolute quantitation (iTRAQ) are more commonly used proteomics techniques in recent years. The differences in proteome expression of plants in response to $\mathrm{Cd}$ stress have been studied in rice (Oryza sativa), Populus tremula, Kandelia candel, Thlaspi caerulescens, Phytolacca americana) and Sedun alfredii and Perilla frutescens (L.) Britt. [3,9], in which ATP activity-related regulatory proteins, detoxification and anti-oxidation and signaling-related proteins, ion transporters, sulfur and glutathione-related metabolic proteins showed differences in expression to cadmium stress [9-12].

Panax notoginseng (Burk.) F.H.Chen is a perennial herb of the Panax genus of Araliaceae family. Saponin is the main medicinal ingredient of $P$. notoginseng, and belongs to the dammarane tetracyclic triterpene substance, which the functions of saponin are related to promote blood circulation, immunity and antitumor. The saponin includes 20(S)-protopanaxadiol and 20(S)-protopanaxatriol [13]. There are more than 70 kinds of monomeric saponins including notoginsenoside $\mathrm{R} 1$ and ginsenosides $\mathrm{Rb} 1$ and $\mathrm{Rg} 1$, in which notoginsenoside $\mathrm{R} 1$ is unique to $P$. notoginseng, and contents of ginsenoside $\mathrm{Rg} 1$ and $\mathrm{Rbl}$ are the highest [14-16]. The synthesis process of saponins in plants includes: (1) synthesis of isopentenyl pyrophosphate and dimethylallyl pyrophosphate; (2) catalytic synthesis of isopentenyl transferase and anthracycline cyclase 2,3-oxidation squalene; (3) cyclized, hydroxylated, glycosylated modified to form dammarane type notoginsenoside. Key enzymes include squalene synthase (SS), farnesyl diphosphate synthase (FPS), squalene epoxidase (SE), and dammarenediol synthase (DS), cytochrome P450, glycosyl transferase (GT), mevalonate kinase (MVK) and $\beta$-amyrin synthase $(\beta$-AS) [13]. The origin and main production area of $P$. notoginseng was located in Wenshan prefecture, Yunnan Province, China. The yield of P. notoginseng in Wenshan prefecture accounts for more than $90 \%$ of total yield in China. The background values of heavy metals in soil of $P$. notoginseng production area are high, which threatens the quality of $P$. notoginseng [17]. $\mathrm{Zu}$ et al. (2017) investigated soil heavy metals contents in Wenshan prefecture, indicating the over-standard rate of soil Cd content was 53.3\% [18]. Control measurements should be taken to reduce $\mathrm{Cd}$ contents in soil and $P$. notoginseng. Environmental stress can change the synthesis of saponin and the expression of relative genes [19]. Other studies showed that contents of notoginsenoside R1 reached a maximum when the soil $\mathrm{Cd}$ content was $6 \mathrm{mg} \mathrm{kg}^{-1}$, and the contents of each monomer saponin and total saponin was significantly decreased when $\mathrm{Cd}$ was $30 \mathrm{mg} \mathrm{kg}{ }^{-1}$ [20]. Reducing the $\mathrm{Cd}$ content and maintaining the contents of saponins are important for high quality of $P$. notoginseng.
Application of lime can increase soil $\mathrm{pH}$ and reduce the bioavailability of heavy metals and the absorption and accumulation of heavy metals by plants [21,22]. Calcium is an essential element of plant growth. The $\mathrm{Ca}^{2+}$ can maintain cell structure stability and cell viability, regulate photosynthesis, signal transduction, transpiration and respiration [19, 23-25]. Under cadmium stress, the supply of calcium can alleviate the degree of chlorophyll decline [26]. The vacuole is the main storage place of the $\mathrm{Ca}^{2+}$. The calcium ion in the vacuole mainly depends on the ions $\mathrm{Ca}^{2+}$ channel to participate in the formation of calcium signal. The $\mathrm{Ca}^{2+}$ in the chloroplast and mitochondria is related to the cell senescence and death [27], the transport of heavy metal ions [28], and abiotic stress [29]). The valence of $\mathrm{Cd}^{2+}$ and $\mathrm{Ca}^{2+}$ is the same and the ionic radius is close. The ions $\mathrm{Ca}^{2+}$ and $\mathrm{Cd}^{2+}$ compete for the adsorption site of the soil. Application of lime significantly reduced the Cd contents of corn [9,21] and rice [30], and increased the biomass of Arabidopsis seedlings [31].

Therefore, the hypothesis include: (1) application of lime under cadmium stress reduces $\mathrm{Cd}$ content in $P$. notoginseng, changes the growth and morphology of $P$. notoginseng roots; (2) Under certain $\mathrm{Ca} / \mathrm{Cd}$ ratio, key enzyme activities and genes expressions related to saponin metabolism change, affecting the monomer heterogeneity and total saponins contents. The iTRAQ proteomics technology was used to study the response mechanism of lime-mediated root growth and saponin metabolism under cadmium stress.

\section{Materials and Methods}

\section{Treatments and Sampling}

One -year old $P$. notoginseng seedling was cultivated in upland red soil. Background values of experiment soil were $\mathrm{pH} 5.42$, CEC $19.4 \mathrm{cmol} \mathrm{kg}^{-1}$, alkali nitrogen $124.61 \mathrm{mg} \mathrm{kg}^{-1}$, available phosphorus $28.77 \mathrm{mg} \mathrm{kg}^{-1}$, available potassium $318.92 \mathrm{mg} \mathrm{kg} \mathrm{kg}^{-1}$, total nitrogen $0.18 \%$, total phosphorus $0.10 \%$, total potassium $1.21 \%$ and $\mathrm{Cd}$ content $0.53 \mathrm{mg} \mathrm{kg}^{-1}$. The experiment site was located at $25^{\circ} 31^{\prime} 21.80^{\prime \prime} \mathrm{N}, 103^{\circ} 17^{\prime} 12.87^{\prime \prime} \mathrm{E}$ and altitude of $1871 \mathrm{~m}$.

Three lime application levels were $0\left(\mathrm{~L}_{0}\right), 0.75\left(\mathrm{~L}_{\mathrm{L}}\right)$ and $1.5\left(\mathrm{~L}_{\mathrm{H}}\right) \mathrm{t} \mathrm{ha} \mathrm{ha}^{-2}$, formulated with $\mathrm{Ca}(\mathrm{OH})_{2}$. The $0-15 \mathrm{~cm}$ layer soil of each plot was mixed with differently treated lime $\mathrm{Six} \mathrm{Cd}$ treatment levels were $0\left(\mathrm{Cd}_{0}\right), 0.6\left(\mathrm{Cd}_{0.6}\right), 3.0\left(\mathrm{Cd}_{3}\right), 6.0\left(\mathrm{Cd}_{6}\right), 9.0\left(\mathrm{Cd}_{9}\right)$, $12 \mathrm{mg} \mathrm{kg}^{-1}\left(\mathrm{Cd}_{12}\right)$, formulated with $\mathrm{CdCl}_{2} \cdot 2.5 \mathrm{H}_{2} \mathrm{O}$. After $\mathrm{CdCl}_{2} \cdot 2.5 \mathrm{H}_{2} \mathrm{O}$ mixed with $2 \mathrm{~mm}$ soil based on the ratio of $1: 40$ of $\mathrm{CdCl}_{2} \cdot 2.5 \mathrm{H}_{2} \mathrm{O}$ : soil, it was evenly spread in each plot, and then mixed with the soil of $0-15 \mathrm{~cm}$. Each treatment was 3 replicates. After 15 days, one -year old $P$. notoginseng seedling were transplanted in February 2016. The experiment plots was randomly arranged. The area of the plot was $1.8 \mathrm{~m}^{2}$ $(1.2 \mathrm{~m} \times 1.5 \mathrm{~m}) .96$ seedlings were transplanted in each 
plot, with a plant spacing of $12 \mathrm{~cm} \times 15 \mathrm{~cm}$. General management was carried through growth periods.

During the vigorous flowering stage of $P$. notoginseng (August 23, 2016), 15 plants of $P$. notoginseng were collected in each plot. The ten plants were used for the determination of $\mathrm{Cd}$ content, root morphology and saponin content, The soil and plants were sampled separately. Four treatments including $\mathrm{L}_{0} \mathrm{Cd}_{0}\left(0 \mathrm{t} \mathrm{ha}^{-2}\right.$ lime $+0 \mathrm{mg} \mathrm{kg} \mathrm{Cd}^{-1}, \mathrm{~L}_{0} \mathrm{Cd}_{6}\left(0 \mathrm{t} \mathrm{ha}^{-2}\right.$ lime + $\left.6.0 \mathrm{mg} \mathrm{kg}^{-1} \mathrm{Cd}\right), \mathrm{L}_{\mathrm{L}} \mathrm{Cd}_{0}\left(0.75 \mathrm{t} \mathrm{ha}^{-2}\right.$ lime $+0 \mathrm{mg} \mathrm{kg}^{-1}$ $\mathrm{Cd})$ and $\mathrm{L}_{\mathrm{L}} \mathrm{Cd}_{6}\left(0.75 \mathrm{t} \mathrm{ha}^{-2}\right.$ lime $\left.+6.0 \mathrm{mg} \mathrm{kg}^{-1} \mathrm{Cd}\right)$ with 3 replicates were selected for proteome analysis of the main root of $P$. notoginseng. The five plants of each treatment used for the enzyme activity and proteomic analysis were washed with ultrapure water and stored in a cryopreservation tube with the liquid nitrogen quickly frozen at $-80^{\circ} \mathrm{C}$.

The soil was air dried and passed through a $1 \mathrm{~mm}$ sieve for the determination of soil $\mathrm{pH}$ and available $\mathrm{Cd}$ content. The plants were first washed with tap water, then washed with deionized water. The roots were scanned by the root scanning analyzer (the Epson Expression 10000XL1.0 root system scanner (Japan)), using the root analysis software WinRHIZO Pro V2007d. (Regina, Canada) to analyze the root morphological characteristics (total root length, root surface area and root volume) of $P$. notoginseng. After the root scanned, the each part of $P$. notoginseng was placed in a blast drying oven, dried at $105^{\circ} \mathrm{C}$ for $30 \mathrm{~min}$, then dried at $65^{\circ} \mathrm{C}$ to a constant weight. After cooling, the biomass of each part of $P$. notoginseng was measured. After grinding through a $1 \mathrm{~mm}$ sieve, it was used to determine the contents of $\mathrm{Cd}$ and saponin of $P$. notoginseng.

\section{Cadmium (Cd) Content in Root of $P$. notoginseng}

Some $0.2 \mathrm{~g}$ of the main root of P. notoginseng was accurately weighed, and placed in a teflon tank and added $2 \mathrm{~mL}$ nitric acid and $1 \mathrm{~mL}$ hydrogen peroxide, then tighten with a stainless steel cover, and place in an oven at $160^{\circ} \mathrm{C}$ for $4 \mathrm{~h}$. After cooling to room temperature, the digestive the mixture was moved to a $10 \mathrm{~mL}$ volumetric flask. The $\mathrm{Cd}$ content of solution was measured by ICP-MS (Nexion 350X, Perkin Elmer, USA).

\section{Saponin Contents in Root of P. notoginseng}

Some $0.6 \mathrm{~g}$ main root powder was accurately weighed, and dissolved in $50 \mathrm{~mL}$ methanol and incubation $12 \mathrm{hr}$ and $1 \mathrm{hr}$ in an $80^{\circ} \mathrm{C}$ water bath. After cooling to room temperature, the mixture was moved to a $50 \mathrm{~mL}$ volumetric flask with adding methanol and filtered for analysis contents of saponin Rb1, saponin Rg1 and notosaponin R1, $10 \mu \mathrm{L}$ using HPLC (Prominence LC-20A, Japan) and the acetonitrile mobile phase $\mathrm{A}$ and aqueous mobile phase $\mathrm{B}$, chromatographic analysis was performed on an octadecylsilyl column under the detection wavelength $203 \mathrm{~nm}$ [16]. Standard regents of $0.4 \mathrm{mg} \mathrm{mL}^{-1}$ saponin $\mathrm{Rg} 1$, saponin $\mathrm{Rbl}$ and $0.1 \mathrm{mg} \mathrm{mL} \mathrm{m}^{-1}$ notosaponin $\mathrm{R} 1$ were used after standard regents dissolved in $1 \mathrm{~mL}$ methanol (The Ministry of Health of Pharmacopoeia Committee 2000). Content of saponin in main root was expressed in unit \% of dry weight.

Samples for HPLC analysis was not necessary to purify according to standard analysis method in China. The parameter of column to HPLC was C18 with particle diameter $5 \mu \mathrm{m}$ and length $200 \mathrm{~mm}$. The detector was SPD. The reagents to HPLC were chromatographic pure from J\&K Scientific LTD, Beijing, China.

The total saponin content of three monomers (Panax notoginseng saponins, PNS) $=\mathrm{Rb} 1+\mathrm{Rg} 1+\mathrm{R} 1$.

Saponin yield of main root $=$ mean of main root biomass $\times$ PNS.

\section{Extraction and Measurement of Enzymes Activities}

Some $0.500 \mathrm{~g}$ of the main root powder was weighed, and put into the frozen mortar. $5 \mathrm{~mL}$ of phosphate buffer was added to grind homogenate, then poured into the centrifuge tube for refrigerated centrifugation. The liquid supernatant was collected. The standard solution was diluted 5 times with a 2-fold dilution gradient in the kit as required. Activities of squalene synthase (SS), mevalonate kinase (MVK), P450 reductase and $\beta$-amyrin synthase $(\beta$-AS): Enzymatic assay was carried out using relative assay kits following manufactory's instruction (Tszelisa, USA) on a ELISA Reader (DNM-9602, Beijing Perlong New technology Limited Company). Enzymatic activity was expressed in units per gram of fresh weight $\left(\mathrm{U} \mathrm{g}^{-1}\right)$.

\section{iTRIQ Transcriptome Analysis}

The main root fresh tissues were ground into powder in liquid nitrogen, homogenized in $1 \mathrm{~mL}$ lysis

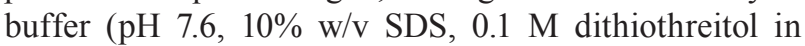
$0.1 \mathrm{M}$ Tris- $\mathrm{HCl}$ ). The mixture was moved to an ice bath for 15 cycles (work $5 \mathrm{~s}$, stop $2 \mathrm{~s}$ ) for sonicating at $35 \mathrm{kHz}$. After super-centrifugation $\left(30000 \mathrm{~g}, 4^{\circ} \mathrm{C}\right.$ for $15 \mathrm{~min}$ ), $10 \%$ trichloroacetic acid/acetone was added to the supernatant with three acetone washes. Protein concentration was measured by Bradford assay protein assay kit (Bio-Rad, United States) after dissolved in the lysis buffer and $100 \mu \mathrm{g}$ aliquots of each sample were used for proteomic experiments. It was used to prepare peptide samples for iTRAQ experiments,including the Filter-aided sample preparation-method (FASP) by Wisniewski et al. (2009), employing ultrafiltration devices to perform SDS removal, buffer exchange, chemical modification, and protein digestion to obtain peptides mixtures.

Trypsin digestion of enzyme to protein ratio 1:50 was carried out at $37^{\circ} \mathrm{C}$ for 4 h. 4-plex iTRAQ labeling experiments were performed according to the manual 
provided by AB SCIEX, Pte. Ltd. (Redwood City, CA, United States) with cation exchange conducted in a GeminiNX 5u C18 110A $150 \mathrm{~mm} \times 4.6 \mathrm{~mm}$ column (Phenomenex, Guangzhou, China) by using a LC-20AB HPLC Pump system (Shimadzu, Japan) [33]. The condition of process included: uv wavelength: $214 \mathrm{~nm}$; flow rate: $1000 \mu \mathrm{L} / \mathrm{min}$; washing-gradient of liquid chromatography: Time(min), B\%: 1, 5\%; $18,30 \% ; 20,80 \% ; 24,80 \% ; 24.1,5 \% ; 30$, stop. Reversed-phase liquid chromatographytandem mass spectrometry were performed by SAGENE, Co., Ltd. (Guangzhou, China) in C18 enriching column ( $3 \mu \mathrm{m}$, ID $100 \mu \mathrm{m}, 20 \mathrm{~mm}$ length) and separation column (1.9 $\mu \mathrm{m}$, ID75 $\mu \mathrm{m}, 100 \mathrm{~mm}$ length) by using a Triple TOF 6600 (Applied Biosystems, United States). The condition of process included: flow rate: $300 \mathrm{~nL} \mathrm{~min}{ }^{-1}$, washing-gradient of liquid chromatography: Time(min), B\%: $0.1,8 \% ; 55,25 \% ; 65,80 \% ; 70,80 \% ; 70.1,2 \%$; $75,2 \%$; stop. The peptides were identified by ProteinPilot 5.0 (AB Sciex) and matched to the reference transcripts of protein sequences of $P$. notoginseng in SwissProt/UniProt database. The statistically significant differentially-accumulated proteins between treatment groups were determined based on protein abundance difference multiple $>1.3$ or $<0.77$ ( $P<0.05$, t-test) [34]. KEGG pathway annotation was performed, and pathway overlaps with DEGs were identified.

\section{Statistical Analysis}

The data of Cd content, saponin content and enzyme activities in the main root of $P$. notoginseng were statistically analyzed using one-way variance (ANOVA) with SPSS 19 software. Least significant difference (LSD) $(P=0.05)$ were calculated.

\section{Results}

\section{Soil pH, Soil Available Cd Content and Cd Content of Panax notoginseng}

The application of lime had a greater impact on soil $\mathrm{pH}$. With the amount of lime applied increased, the $\mathrm{pH}$ gradually increased. Under $0,0.6,3.0,6.0$, 9.0, $12.0 \mathrm{mg} \mathrm{kg}^{-1} \mathrm{Cd}$ treatments, the soil $\mathrm{pH}$ increased by $14.4-22.0 \%, \quad 8.7-10.7 \%, \quad 8.5-13.0 \%, \quad 10.6-15.2 \%$, $8.9-16.5 \%$, and $17.0-19.0 \%$, respectively, with 0.75 and $1.5 \mathrm{t} \mathrm{ha}^{-2}$ lime application (Table 1).

When the application level of lime was consistent, the soil effective $\mathrm{Cd}$ contents increased significantly with the increase in $\mathrm{Cd}$ treatment levels. When the treatment level of $\mathrm{Cd}$ was the same, the soil effective $\mathrm{Cd}$ content decreased significantly with increase in the amount of lime applied (Table 1). The effective $\mathrm{Cd}$ content decreased by $3.3-38.0 \%$ with 0.75 and $1.5 \mathrm{t} \mathrm{ha}^{-2}$ lime application compared to the non-lime treatment. Correlation analysis showed that there was a significant negative correlation between soil available $\mathrm{Cd}$ content and $\mathrm{Ca} / \mathrm{Cd}$ treatment ratio $(\mathrm{R}=-0.738, \mathrm{~F}=9.589$, $P<0.05, \mathrm{~N}=10$ ).

With the amount of $\mathrm{Cd}$ treatment increased, the $\mathrm{Cd}$ content of the main root of $P$. notoginseng increased significantly. Under the same treatment amount of $\mathrm{Cd}$, the $\mathrm{Cd}$ content of the main root of $P$. notoginseng decreases with the increase in lime application levels. Under $0,3.0$ and $12.0 \mathrm{mg} \mathrm{kg}^{-1} \mathrm{Cd}$ treatments, the $\mathrm{Cd}$ content of the main root of $P$. notoginseng was significantly decreased by $13.3 \%, 12.5 \%$ and $17.5 \%$ with $1.5 \mathrm{t} \mathrm{ha}^{-2}$ lime application. Under 0.6, 6.0 and $9.0 \mathrm{mg} \mathrm{kg}{ }^{-1} \mathrm{Cd}$ treatments, there was no significant changes in the $\mathrm{Cd}$ content in the main root of $P$. notoginseng (Table 1). Correlation analysis showed that there was a significant positive correlation between the $\mathrm{Cd}$ content of the main root and the soil effective $\mathrm{Cd}$

Table 1. Soil $\mathrm{pH}$ and available Cd contents, Cd content in main root of Panax notoginseng.

\begin{tabular}{|c|c|c|c|c|c|c|c|}
\hline \multirow{2}{*}{ Parameters } & \multirow{2}{*}{$\begin{array}{l}\text { Lime } \\
/ \mathrm{tha}^{-2}\end{array}$} & \multicolumn{6}{|c|}{$\mathrm{Cd} / \mathrm{mg} \mathrm{kg}^{-1}$} \\
\hline & & 0 & 0.6 & 3.0 & 6.0 & 9.0 & 12.0 \\
\hline \multirow{3}{*}{ Soil pH } & 0 & $5.42 \pm 0.17 \mathrm{c}$ & $5.77 \pm 0.10 \mathrm{~b}$ & $5.75 \pm 0.03 \mathrm{c}$ & $5.66 \pm 0.03 b$ & $5.64 \pm 0.12 \mathrm{c}$ & $5.41 \pm 0.03 b$ \\
\hline & 0.75 & $6.20 \pm 0.09 b$ & $6.27 \pm 0.10 \mathrm{a}$ & $6.24 \pm 0.04 b$ & $6.26 \pm 0.21 \mathrm{a}$ & $6.14 \pm 0.05 b$ & $6.33 \pm 0.07 \mathrm{a}$ \\
\hline & 1.5 & $6.61 \pm 0.1 \mathrm{a}$ & $6.39 \pm 0.09 \mathrm{a}$ & $6.50 \pm 0.14 \mathrm{a}$ & $6.52 \pm 0.12 \mathrm{a}$ & $6.57 \pm 0.11 \mathrm{a}$ & $6.44 \pm 0.07 \mathrm{a}$ \\
\hline \multirow{3}{*}{$\begin{array}{l}\text { Soil available } \mathrm{Cd} \\
\text { contents } / \mathrm{mg} \mathrm{kg}^{-1}\end{array}$} & 0 & $0.24 \pm 0.02 \mathrm{a}$ & $0.79 \pm 0.04 \mathrm{a}$ & $2.47 \pm 0.21 \mathrm{a}$ & $4.58 \pm 0.18 \mathrm{a}$ & $7.09 \pm 0.22 \mathrm{a}$ & $8.32 \pm 0.16 \mathrm{a}$ \\
\hline & 0.75 & $0.18 \pm 0.02 b$ & $0.61 \pm 0.04 \mathrm{~b}$ & $2.24 \pm 0.16 \mathrm{ab}$ & $4.43 \pm 0.34 \mathrm{a}$ & $6.56 \pm 0.24 \mathrm{a}$ & $7.74 \pm 0.19 \mathrm{ab}$ \\
\hline & 1.5 & $0.17 \pm 0.01 \mathrm{~b}$ & $0.49 \pm 0.02 \mathrm{c}$ & $1.99 \pm 0.13 b$ & $4.16 \pm 0.32 \mathrm{a}$ & $5.76 \pm 0.27 b$ & $7.13 \pm 0.40 \mathrm{~b}$ \\
\hline \multirow{3}{*}{$\begin{array}{l}\mathrm{Cd} \text { contents in main } \\
\text { root } / \mathrm{mg} \mathrm{kg}^{-1}\end{array}$} & 0 & $0.15 \pm 0.01 \mathrm{a}$ & $0.31 \pm 0.02 \mathrm{a}$ & $0.48 \pm 0.04 \mathrm{a}$ & $0.89 \pm 0.03 \mathrm{a}$ & $1.13 \pm 0.07 \mathrm{a}$ & $1.43 \pm 0.10 \mathrm{a}$ \\
\hline & 0.75 & $0.14 \pm 0.00 \mathrm{ab}$ & $0.31 \pm 0.02 \mathrm{a}$ & $0.45 \pm 0.03 \mathrm{ab}$ & $0.87 \pm 0.03 \mathrm{a}$ & $1.05 \pm 0.08 \mathrm{a}$ & $1.31 \pm 0.02 \mathrm{a}$ \\
\hline & 1.5 & $0.13 \pm 0.00 \mathrm{~b}$ & $0.29 \pm 0.02 \mathrm{a}$ & $0.42 \pm 0.01 \mathrm{~b}$ & $0.84 \pm 0.03 a$ & $1.00 \pm 0.03 \mathrm{a}$ & $1.18 \pm 0.04 \mathrm{~b}$ \\
\hline
\end{tabular}

Note: The data are mean \pm standard deviation. Different lowercase letters indicate difference significantly between lime treatments at $P<0.05$ levels with t-test, $\mathrm{n}=3$. 


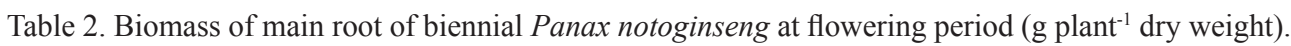

\begin{tabular}{|c|c|c|c|c|c|c|}
\hline \multirow{2}{*}{ Lime $/ \mathrm{t} \mathrm{ha}^{-2}$} & \multicolumn{5}{|c|}{$\mathrm{Cd} / \mathrm{mg} \mathrm{kg}^{-1}$} \\
\cline { 2 - 7 } & 0 & 0.6 & 3.0 & 6.0 & 9.0 & 12.0 \\
\hline 0 & $0.17 \pm 0.03 \mathrm{a}$ & $0.18 \pm 0.03 \mathrm{a}$ & $0.18 \pm 0.03 \mathrm{c}$ & $0.27 \pm 0.01 \mathrm{a}$ & $0.24 \pm 0.04 \mathrm{a}$ & $0.25 \pm 0.04 \mathrm{a}$ \\
\hline 0.75 & $0.17 \pm 0.02 \mathrm{a}$ & $0.26 \pm 0.08 \mathrm{a}$ & $0.22 \pm 0.03 \mathrm{~b}$ & $0.25 \pm 0.02 \mathrm{a}$ & $0.22 \pm 0.01 \mathrm{a}$ & $0.20 \pm 0.04 \mathrm{a}$ \\
\hline 1.5 & $0.21 \pm 0.05 \mathrm{a}$ & $0.17 \pm 0.02 \mathrm{a}$ & $0.31 \pm 0.02 \mathrm{a}$ & $0.21 \pm 0.04 \mathrm{a}$ & $0.29 \pm 0.01 \mathrm{a}$ & $0.27 \pm 0.03 \mathrm{a}$ \\
\hline
\end{tabular}

content $(\mathrm{R}=0.992, \mathrm{~F}=502.665, P<0.001, \mathrm{~N}=10)$, and there was a significant negative relationship between the $\mathrm{Cd}$ content of the main root and the $\mathrm{Ca} / \mathrm{Cd}$ treatment ratio $(\mathrm{R}=-0.709, \mathrm{~F}=8.072, P<0.05, \mathrm{~N}=10)$.

\section{Biomass and Morphological Characteristics of Roots}

Under $3.0 \mathrm{mg} \mathrm{kg}^{-1} \mathrm{Cd}$ treatment, the biomass of main root increased by $22-72 \%$ with the increase in lime
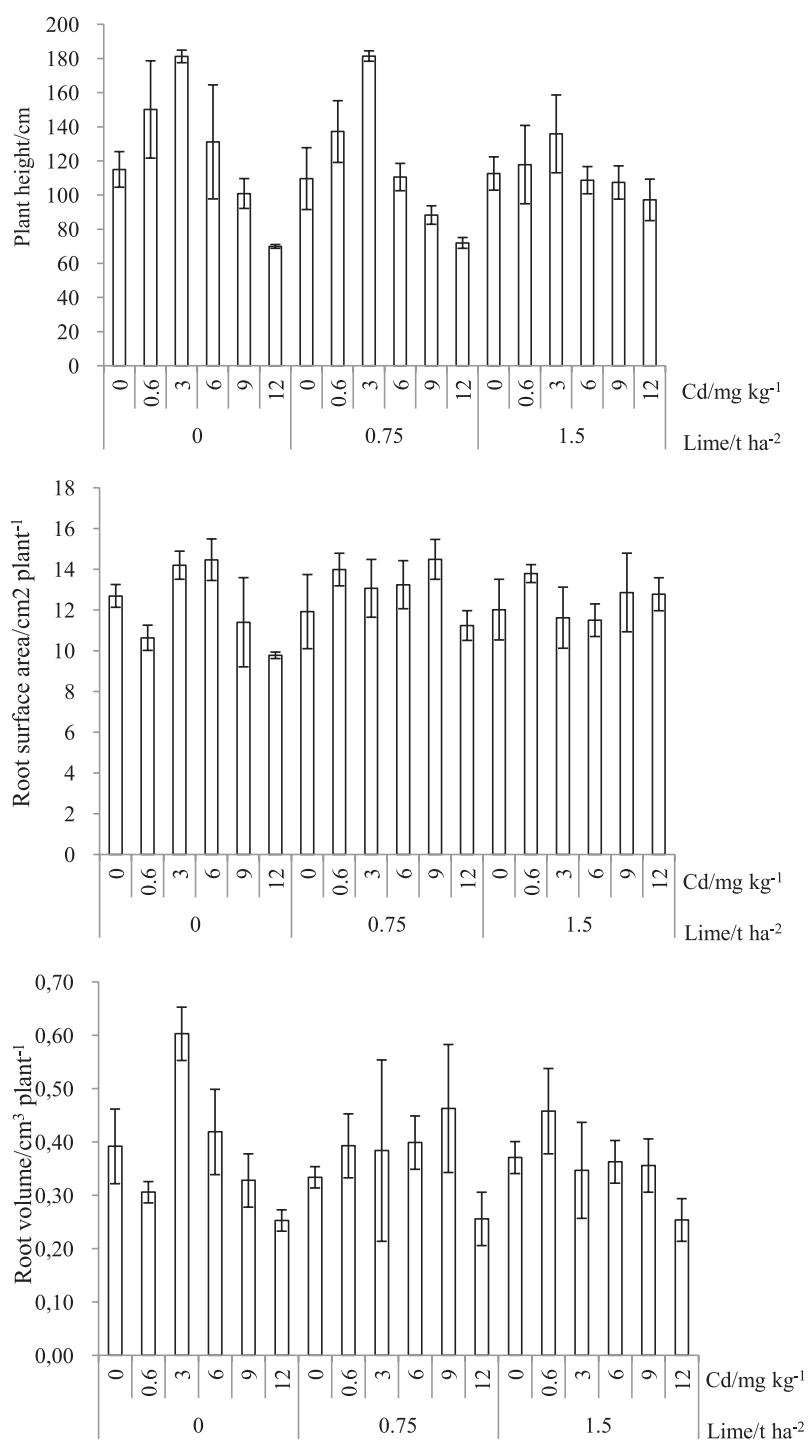

Fig. 1. Effects of $\mathrm{Cd}$ and lime on root length, surface area and volume of Panax notoginseng. application levels. Compared with other treatments, the biomass of main root of $P$. notoginseng was the highest with $3.0 \mathrm{mg} \mathrm{kg}^{-1} \mathrm{Cd}$ and $1.5 \mathrm{t} \mathrm{ha}^{-2}$ lime treatment (Table 2).

Under the same lime treatment, the root length increased first and then decreased, and the root surface area and root volume decreased with the increase in $\mathrm{Cd}$ treatment levels. Under the 9.0 and $12.0 \mathrm{mg} \mathrm{kg}{ }^{-1} \mathrm{Cd}$ treatments, the root length, root surface area and root volume under lime $1.5 \mathrm{t} \mathrm{ha}^{-2}$ treatment were greater than those non-lime treatment (Fig. 1). Under 3.0 and $6.0 \mathrm{mg} \mathrm{kg}{ }^{-1} \mathrm{Cd}$ treatments, the root surface area and root volume showed a decreasing trend with lime application. Correlation analysis showed that there were significant negative correlations between root length and soil available $\mathrm{Cd}$ content $(\mathrm{R}=-0.745, \mathrm{~F}=9.959$, $P<0.05, \mathrm{~N}=10)$, Cd content of main root $(\mathrm{R}=-0.784$, $\mathrm{F}=12.769, P<0.01, \mathrm{~N}=10)$.

\section{Content of Saponins of Panax notoginseng and its Related Enzyme Activities}

\section{Saponins Contents}

Under $0.6,6.0$ and $12.0 \mathrm{mg} \mathrm{kg}^{-1} \mathrm{Cd}$ treatments, the contents of saponins in the main root of $P$. notoginseng decreased with the increase in 0.75 and $1.5 \mathrm{t} \mathrm{ha}^{-2}$ lime treatments. The content of saponins decreased by 4.8- $23.6 \%$ with lime application. The saponin content decreased by $23.6 \%$ under $0.6 \mathrm{mg} \mathrm{kg}^{-1} \mathrm{Cd}$ and $1.5 \mathrm{t} \mathrm{ha}^{-2}$ lime application (Fig. 2).

The contents of three monomeric saponins showed in order: Ginsenoside Rgl>ginsenoside $\mathrm{Rbl}>$ notoginsenoside $\mathrm{R} 1$, three monomeric saponins and total saponin content reached the maximum at $0.75 \mathrm{t} \mathrm{ha}^{-2}$ lime $+3.0 \mathrm{mg} \mathrm{kg}^{-1} \mathrm{Cd}$ treatment, which was $0.45 \%$ notoginsenoside R1， $1.62 \%$ ginsenoside $\mathrm{Rg}$, $0.97 \%$ ginsenoside $\mathrm{Rb} 1$ and $3.03 \%$ total saponin. The ratio of $\mathrm{Rg} 1$ to $\mathrm{Rb1}$ was the highest under $0.6 \mathrm{mg} \mathrm{kg}^{-1}$ $\mathrm{Cd}$ treatment. With 0 and $0.75 \mathrm{t} \mathrm{ha}^{-2}$ lime applications, the ratio of $\mathrm{R} 1 /(\mathrm{Rg} 1+\mathrm{Rb} 1)$ was the highest under $0.6 \mathrm{mg} \mathrm{kg}-1$ Cd treatment. The ratio of $\mathrm{R} 1 /(\mathrm{Rg} 1+\mathrm{Rb} 1)$ was the highest with $0.75 \mathrm{t} \mathrm{ha}^{-2}$ lime application and $6 \mathrm{mg} \mathrm{kg}^{-1} \mathrm{Cd}$ treatment (Fig. 2). Correlation analysis showed that there were significant negative correlations between the ratio of $\mathrm{Rg} 1 / \mathrm{Rb} 1$ and soil effective $\mathrm{Cd}$ content $(\mathrm{R}=-0.677, \mathrm{~F}=6.767, P<0.05, \mathrm{~N}=10), \mathrm{Cd}$ content of main root $(\mathrm{R}=-0.644, \mathrm{~F}=5.671, P<0.05$, 

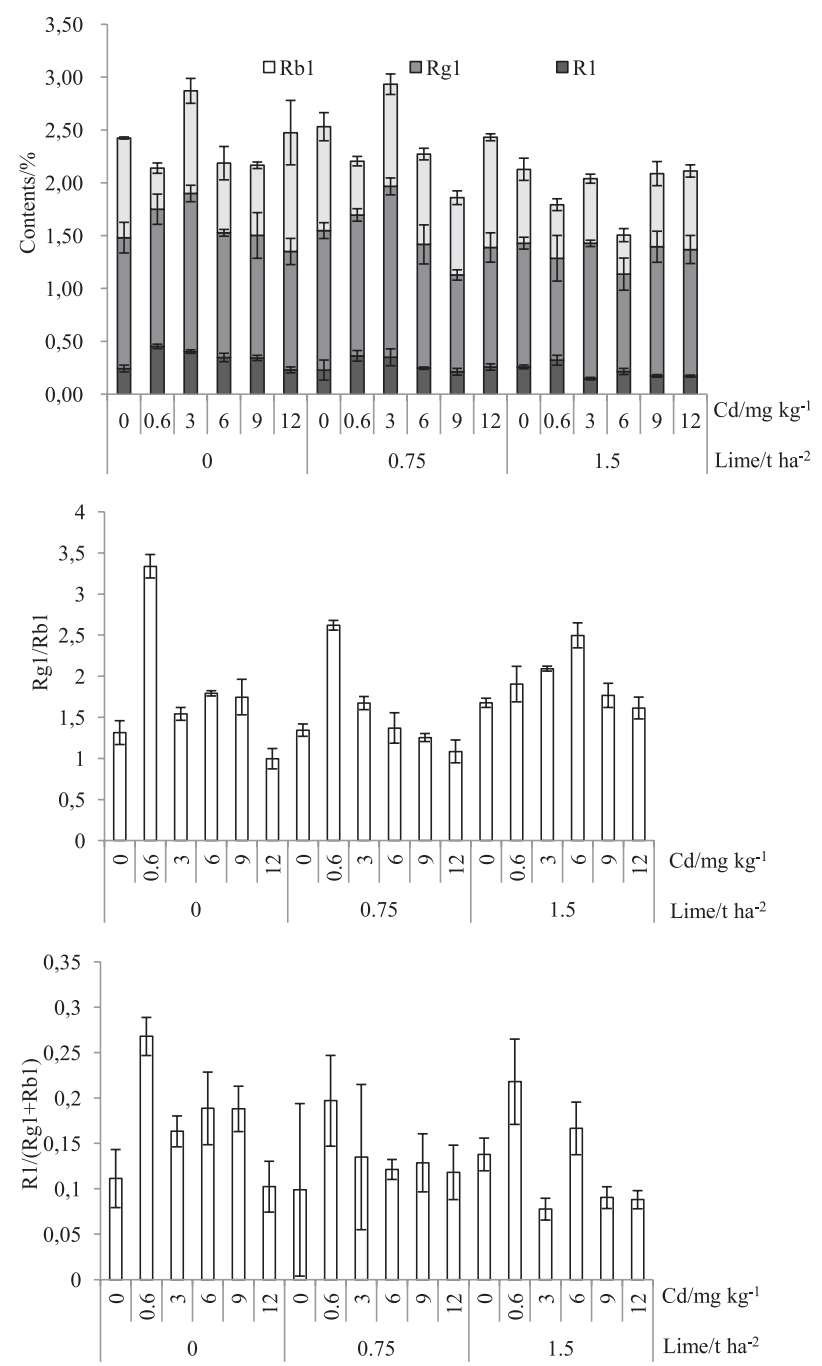

Fig. 2. Saponins contents and ratios of $\mathrm{Rg} 1 / \mathrm{Rb} 1$ and $\mathrm{R} 1 /$ $(\mathrm{Rg} 1+\mathrm{Rb} 1)$ in main root of Panax notoginseng.

$\mathrm{N}=10$ ); There was a significant quadratic correlation between the ratio of $\mathrm{Rg} 1 / \mathrm{Rb} 1$ and the $\mathrm{Ca} / \mathrm{Cd}$ treatment ratio $\left(\mathrm{Y}=1.28+0.009 \mathrm{X}-1.32 \times 10^{-5} \mathrm{X}^{2}, \mathrm{R}=0.815\right.$, $\mathrm{F}=6.925, \mathrm{P}<0.05, \mathrm{~N}=10$ ). (The ratio of $\mathrm{Rg} 1 / \mathrm{Rb} 1$ was the highest when $\mathrm{Ca} / \mathrm{Cd}$ treatment ratio 682 ); There was a significant logarithm correlation between $\mathrm{R} 1 /(\mathrm{Rg} 1+\mathrm{Rb} 1)$ ratio and $\mathrm{Ca} / \mathrm{Cd}$ treatment ratio $(\mathrm{Y}=0.022+\operatorname{LnX}, \mathrm{R}=0.689), \mathrm{F}=7.217, \mathrm{P}<0.05$, $\mathrm{N}=10$ ).

\section{Related Enzyme Activities}

The SS enzyme activity was the lowest under $12.0 \mathrm{mg} \mathrm{kg}{ }^{-1} \mathrm{Cd}$ treatment. The SS activity in the main roots increased significantly under $0.6,3.0$ and $12 \mathrm{mg} \mathrm{kg}^{-1} \mathrm{Cd}$ treatment and $0.75 \mathrm{t} \mathrm{ha}^{-2}$ lime application. With $1.5 \mathrm{t} \mathrm{ha}^{-2}$ application, SS activity was significantly increased in the main root under 0.6 and $3.0 \mathrm{mg} \mathrm{kg}^{-1}$ $\mathrm{Cd}$ treatments. The SS activity in the main root was the highest under $12.0 \mathrm{mg} \mathrm{kg}^{-1} \mathrm{Cd}$ treatment and $0.75 \mathrm{t} \mathrm{ha}^{-2}$ lime application (Table 3). Correlation analysis showed that there were negative relationships between SS activity and soil effective $\mathrm{Cd}$ content $(\mathrm{R}=-0.747$, $\mathrm{F}=10.102, P<0.05, \mathrm{~N}=10), \mathrm{Cd}$ content of main root $(\mathrm{R}=-0.765, \mathrm{~F}=11.317, P<0.05, \mathrm{~N}=10)$. There were significant positive correlations between SS activity and $\mathrm{R} 1$ content $(\mathrm{R}=0.723, \mathrm{~F}=8.745, P<0.05, \mathrm{~N}=10), \mathrm{Rg} 1$ content $(\mathrm{R}=0.646, \mathrm{~F}=5.717, P<0.05, \mathrm{~N}=10)$.

Mevalonate kinase (MVK) activities increased under $0.6 \mathrm{mg} \mathrm{kg}^{-1} \mathrm{Cd}$ treatment without application of lime. MVK activity was inhibited under other $\mathrm{Cd}$ treatments, and the inhibitory effect increased with increase in $\mathrm{Cd}$ treatment concentrations. Under the same Cd treatment, the activities of mevalonate kinase gradually decreased with the increase in lime application levels. There was a significant difference in the MVK activity under 0 and $3.0 \mathrm{mg} \mathrm{kg}^{-1} \mathrm{Cd}$ treatments with lime application comparing with non-lime application. There was no significant different of MVK activity between $0.75 \mathrm{t} \mathrm{ha}^{-2}$ and $1.5 \mathrm{t} \mathrm{ha}^{-2}$ lime applications. Under $6.0 \mathrm{mg} \mathrm{kg}^{-1} \mathrm{Cd}$ treatment, there was no significant difference between the applications of $0.75 \mathrm{t} \mathrm{ha}^{-2}$ lime and non-lime.The MVK activity decreased significantly when $1.5 \mathrm{t} \mathrm{ha}^{-2}$ lime application.Under $9.0 \mathrm{mg} \mathrm{kg}^{-1} \mathrm{Cd}$ treatment or more, the MVK activities significantly decreased. There were significant difference of MVK activities between $0.75 \mathrm{t} \mathrm{ha}^{-2}$ and $1.5 \mathrm{t} \mathrm{ha}^{-2}$ application.

P450 reductase activity decreased with the increase in $\mathrm{Cd}$ treatment concentrations under the same lime application. Under the same Cd treatment level, P450 reductase activity decreased with the increase in lime application levels. Under 0, 0.6, 3.0, 6.0, 9.0 and $12.0 \mathrm{mg} \mathrm{kg}^{-1} \mathrm{Cd}$ treatments, the $\mathrm{P} 450$ reductase activities with $0.75 \mathrm{t} \mathrm{ha}^{-2}$ and $1.5 \mathrm{t} \mathrm{ha}^{-2}$ lime application reduced by $27.7-40.8 \%, 10.0-37.2 \%, 38.6-41.9 \%, 24.6-32.6 \%$, $40.5-60 \%$, and $45.2-63.3 \%$ compared with non-lime application, respectively. Correlation analysis showed that there were significant negative correlations between $\mathrm{P} 450$ reductase activity and soil effective $\mathrm{Cd}$ content $(\mathrm{R}=-0.770, \mathrm{~F}=11.658, P<0.01, \mathrm{~N}=10), \mathrm{Cd}$ content of main root $(\mathrm{R}=-0.750, \mathrm{~F}=10.257, P<0.05, \mathrm{~N}=10)$. There was a significant quadratic correlation between P450 reductase activity and $\mathrm{Ca} / \mathrm{Cd}$ treatment ratio $\left(\mathrm{Y}=0.85+0.006 \mathrm{X}-8.62 \times 10^{-6} \mathrm{X}^{2}, \mathrm{R}=0.809\right.$, $\mathrm{F}=6.612, P<0.05, \mathrm{~N}=10)(\mathrm{P} 450$ reductase activity was highest when $\mathrm{Ca} / \mathrm{Cd}$ treatment ratio was 696). There were significant positive correlations between P450 reductase activity and $\mathrm{R} 1$ content $(\mathrm{R}=0.716, \mathrm{~F}=8.433$, $P<0.05, \mathrm{~N}=10)$, ratio of $\mathrm{R} 1 /(\mathrm{Rg} 1+\mathrm{Rb} 1) \quad(\mathrm{R}=0.709$, $\mathrm{F}=8.109, P<0.05, \mathrm{~N}=10$ ).

When lime was not applied, the $\beta$-amyrin synthase $(\beta$-AS) activity decreased with increase in $0-6.0 \mathrm{mg} \mathrm{kg}{ }^{-1} \mathrm{Cd}$ treatment concentration. The $\beta$-AS activities gradually decreased with increase in $\mathrm{Cd}$ treatment concentrations under $0.75 \mathrm{t} \mathrm{ha}^{-2}$ and $1.5 \mathrm{t} \mathrm{ha}^{-2}$ lime application.The $\beta$-AS activities decreased with increase in lime application levels under the same $\mathrm{Cd}$ treatment concentration. The $\beta$-AS activity was $75.95 \mathrm{U} \mathrm{g} \mathrm{g}^{-1}$, which was the lowest under $0.75 \mathrm{t} \mathrm{ha}^{-2}$ application and $9.0 \mathrm{mg} \mathrm{kg}^{-1} \mathrm{Cd}$ treatment. The $\beta$-AS 
Table 3. Activities of SS, MVK, P450 and $\beta$-AS in main root of Panax notoginseng.

\begin{tabular}{|c|c|c|c|c|c|c|c|}
\hline \multirow{3}{*}{ Enzymes/U g } & \multirow{2}{*}{ Lime $/ \mathrm{tha}^{-2}$} & \multicolumn{6}{|c|}{$\mathrm{Cd} / \mathrm{mg} \mathrm{kg}^{-1}$} \\
\cline { 3 - 8 } & & 0 & 0.6 & 3.0 & 6.0 & 9.0 & 12.0 \\
\hline \multirow{3}{*}{ SS } & 0 & $0.17 \pm 0.01 \mathrm{a}$ & $0.17 \pm 0.01 \mathrm{~b}$ & $0.18 \pm 0.01 \mathrm{~b}$ & $0.21 \pm 0.02 \mathrm{a}$ & $0.18 \pm 0.01 \mathrm{a}$ & $0.15 \pm 0.01 \mathrm{~b}$ \\
\cline { 2 - 8 } & 0.75 & $0.17 \pm 0.01 \mathrm{a}$ & $0.22 \pm 0.07 \mathrm{a}$ & $0.25 \pm 0.06 \mathrm{a}$ & $0.18 \pm 0.01 \mathrm{a}$ & $0.17 \pm 0.01 \mathrm{a}$ & $0.18 \pm 0.01 \mathrm{a}$ \\
\hline \multirow{3}{*}{ MVK } & 1.5 & $0.17 \pm 0.01 \mathrm{a}$ & $0.20 \pm 0.02 \mathrm{a}$ & $0.20 \pm 0.01 \mathrm{a}$ & $0.19 \pm 0.01 \mathrm{a}$ & $0.18 \pm 0.02 \mathrm{a}$ & $0.15 \pm 0.02 \mathrm{~b}$ \\
\cline { 2 - 8 } & 0 & $9.45 \pm 0.82 \mathrm{a}$ & $10.33 \pm 0.76 \mathrm{a}$ & $8.50 \pm 0.39 \mathrm{a}$ & $7.69 \pm 0.59 \mathrm{a}$ & $7.47 \pm 0.88 \mathrm{a}$ & $6.05 \pm 0.88 \mathrm{a}$ \\
\cline { 2 - 8 } & 1.5 & $5.64 \pm 1.47 \mathrm{~b}$ & $8.13 \pm 0.45 \mathrm{~b}$ & $5.30 \pm 0.12 \mathrm{~b}$ & $5.19 \pm 1.06 \mathrm{~b}$ & $7.68 \pm 0.33 \mathrm{c}$ & $3.40 \pm 0.23 \mathrm{c}$ \\
\hline \multirow{3}{*}{ P450 } & 0 & $3.11 \pm 0.13 \mathrm{a}$ & $2.31 \pm 0.20 \mathrm{a}$ & $2.15 \pm 0.03 \mathrm{a}$ & $1.75 \pm 0.16 \mathrm{a}$ & $2.15 \pm 0.21 \mathrm{a}$ & $1.77 \pm 0.42 \mathrm{a}$ \\
\cline { 2 - 8 } & 0.75 & $2.25 \pm 0.45 \mathrm{~b}$ & $2.08 \pm 0.21 \mathrm{a}$ & $1.32 \pm 0.14 \mathrm{~b}$ & $1.32 \pm 0.36 \mathrm{ab}$ & $1.28 \pm 0.43 \mathrm{~b}$ & $0.97 \pm 0.22 \mathrm{~b}$ \\
\cline { 2 - 8 } & 1.5 & $1.84 \pm 0.03 \mathrm{~b}$ & $1.45 \pm 0.21 \mathrm{~b}$ & $1.25 \pm 0.48 \mathrm{~b}$ & $1.18 \pm 0.16 \mathrm{~b}$ & $0.86 \pm 0.08 \mathrm{~b}$ & $0.65 \pm 0.14 \mathrm{~b}$ \\
\hline \multirow{3}{*}{$\beta$-AS } & 0 & $115.57 \pm 19.03 \mathrm{a}$ & $107.87 \pm 13.40 \mathrm{a}$ & $101.11 \pm 20.10 \mathrm{a}$ & $90.30 \pm 10.58 \mathrm{a}$ & $137.08 \pm 1.12 \mathrm{a}$ & $125.71 \pm 20.40 \mathrm{a}$ \\
\cline { 2 - 8 } & 0.75 & $110.83 \pm 16.86 \mathrm{a}$ & $98.85 \pm 10.86 \mathrm{ab}$ & $92.76 \pm 14.71 \mathrm{a}$ & $77.06 \pm 16.29 \mathrm{a}$ & $75.95 \pm 17.81 \mathrm{~b}$ & $80.44 \pm 7.84 \mathrm{~b}$ \\
\cline { 2 - 8 } & 1.5 & $86.10 \pm 4.46 \mathrm{a}$ & $81.01 \pm 5.76 \mathrm{c}$ & $52.68 \pm 9.29 \mathrm{~b}$ & $53.01 \pm 5.18 \mathrm{~b}$ & $37.71 \pm 3.90 \mathrm{c}$ & $23.74 \pm 10.75 \mathrm{c}$ \\
\hline
\end{tabular}

activity was $23.74 \mathrm{U} \mathrm{g}^{-1}$, which was the lowest under $1.5 \mathrm{t} \mathrm{ha}^{-2}$ application and $12.0 \mathrm{mg} \mathrm{kg}^{-1} \mathrm{Cd}$ treatment. There were significant positive correlations between $\beta$-AS activity and $\mathrm{R} 1$ content $(\mathrm{R}=0.866, \mathrm{~F}=24.082$, $P<0.01, \mathrm{~N}=10)$, ratio of $\mathrm{R} 1 /(\mathrm{Rg} 1+\mathrm{Rb} 1)(\mathrm{R}=0.629$, $\mathrm{F}=5.230, P<0.05, \mathrm{~N}=10$ ).
Expression of Related Proteins in the Synthesis of Saponins of Panax notoginseng

When lime was applied under Cd stress, 328122 total spectra were obtained by iTRAQ analysis with unique spectra 5918, unique peptide 2862, and 1181

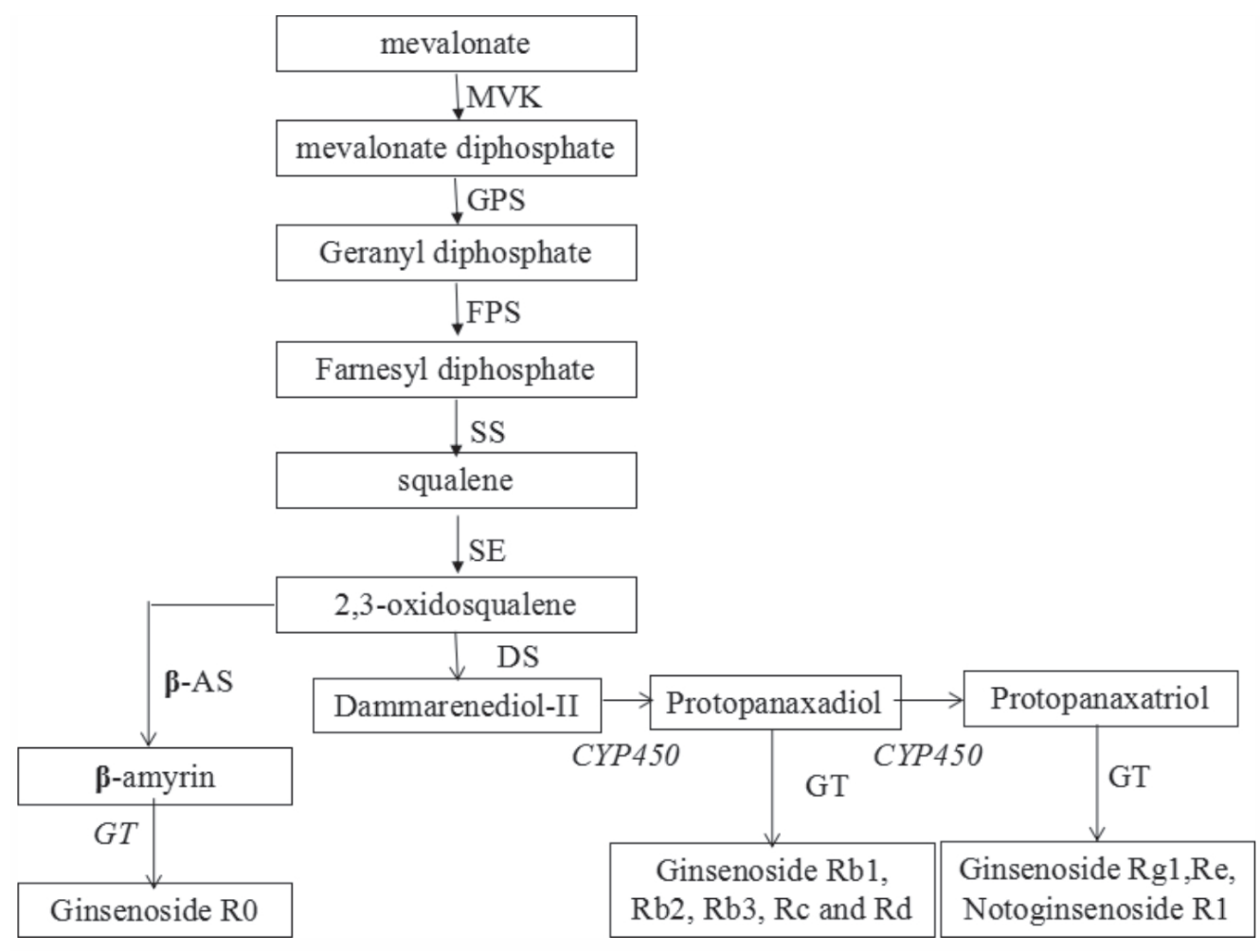

Fig. 3. Saponins biosynthesis pathway of Panax notoginseng.

Note: mevalonate kinase (MVK), geranyl pyrophosphate synthase(GPS), farnesyl diphosphate synthase (FPS), squalene synthase (SS), squalene epoxidase (SE), dammarenediol synthase (DS), cytochrome P450, $\beta$-amyrin synthase ( $\beta$-AS), glycosyl transferase(GT). 
Table 4. Functional classification of differentially expressed proteins (DEPs).

\begin{tabular}{|c|c|c|c|c|c|c|c|c|}
\hline DEPs & Protein ID & Coverage & $\begin{array}{l}\text { Unique } \\
\text { spectrum }\end{array}$ & $\begin{array}{l}\text { Unique } \\
\text { peptide }\end{array}$ & $\begin{array}{c}\text { Difference } \\
\text { multiple } \pm \text { SD }\end{array}$ & $P$ value & $\begin{array}{l}\text { Up/ } \\
\text { Down }\end{array}$ & $\begin{array}{l}\text { Comparison } \\
\text { group }\end{array}$ \\
\hline \multirow{2}{*}{$\mathrm{P} 450(C Y P 72 A 129)$} & Unigene 0012926 & 0.095 & 1 & 1 & $0.66 \pm 0.08$ & 0.000 & Down & $\mathrm{L}_{\mathrm{L}} \mathrm{Cd}_{6} / \mathrm{L}_{0} \mathrm{Cd}_{0}$ \\
\hline & Unigene 0050708 & 0.024 & 1 & 1 & $0.58 \pm 0.23$ & 0.006 & Down & $\mathrm{L}_{0} \mathrm{Cd}_{6} / \mathrm{L}_{0} \mathrm{Cd}_{0}$ \\
\hline $\begin{array}{c}\mathrm{P} 450 \\
(C Y P 72 A 129-\text { like })\end{array}$ & Unigene 0047723 & 0.045 & 1 & 1 & $0.59 \pm 0.09$ & 0.000 & Down & $\mathrm{L}_{\mathrm{L}} \mathrm{Cd}_{6} / \mathrm{L}_{0} \mathrm{Cd}_{0}$ \\
\hline \multirow{2}{*}{ P450(CYP736A54) } & \multirow{2}{*}{ Unigene 0014832} & 0.051 & 1 & 1 & $1.75 \pm 0.58$ & 0.025 & Up & $\mathrm{L}_{\mathrm{L}} \mathrm{Cd}_{6} / \mathrm{L}_{0} \mathrm{Cd}_{0}$ \\
\hline & & 0.051 & 1 & 1 & $1.54 \pm 0.39$ & 0.024 & Up & $\mathrm{L}_{0} \mathrm{Cd}_{6} / \mathrm{L}_{0} \mathrm{Cd}_{0}$ \\
\hline P450 reductase & Unigene 0031564 & 0.074 & 1 & 1 & $0.66 \pm 0.07$ & 0.002 & Down & $\mathrm{L}_{\mathrm{L}} \mathrm{Cd}_{0} / \mathrm{L}_{0} \mathrm{Cd}_{0}$ \\
\hline$\beta$-AS & Unigene 0011395 & 0.028 & 1 & 1 & $0.62 \pm 0.05$ & 0.000 & Down & $\mathrm{L}_{\mathrm{L}} \mathrm{Cd}_{0} / \mathrm{L}_{0} \mathrm{Cd}_{0}$ \\
\hline $\begin{array}{c}\text { glycosyl transferase } \\
\text { UDP } 84 B 1\end{array}$ & Unigene 0032248 & 0.022 & 1 & 1 & $2.14 \pm 0.76$ & 0.015 & Up & $\mathrm{L}_{\mathrm{L}} \mathrm{Cd}_{6} / \mathrm{L}_{0} \mathrm{Cd}_{0}$ \\
\hline $\begin{array}{l}\text { UDP-glycosyl } \\
\text { transferase }\end{array}$ & Unigene0049934 & 0.108 & 6 & 5 & $0.63 \pm 0.08$ & 0.003 & Down & $\mathrm{L}_{\mathrm{L}} \mathrm{Cd}_{0}-\mathrm{L}_{0} \mathrm{Cd}_{0}$ \\
\hline \multirow{3}{*}{$\begin{array}{l}\text { UDP-glycosyl } \\
\text { transferase } \\
(U G T P g 34)\end{array}$} & Unigene 0003621 & 0.035 & 1 & 1 & $0.64 \pm 0.28$ & 0.024 & Down & $\mathrm{L}_{0} \mathrm{Cd}_{6} / \mathrm{L}_{0} \mathrm{Cd}_{0}$ \\
\hline & & 0.35 & 1 & 1 & $0.66 \pm 0.18$ & 0.029 & Down & $\mathrm{L}_{\mathrm{L}} \mathrm{Cd}_{0} / \mathrm{L}_{0} \mathrm{Cd}_{0}$ \\
\hline & & 0.35 & 1 & 1 & $0.61 \pm 0.26$ & 0.015 & Down & $\mathrm{L}_{\mathrm{L}} \mathrm{Cd}_{6} / \mathrm{L}_{0} \mathrm{Cd}_{0}$ \\
\hline $\begin{array}{c}\text { UDP-glycosyl } \\
\text { transferase(UGTPg19) }\end{array}$ & Unigene 0040383 & 0.025 & 1 & 1 & $0.64 \pm 0.09$ & 0.000 & Down & $\mathrm{L}_{\mathrm{L}} \mathrm{Cd}_{6} / \mathrm{L}_{0} \mathrm{Cd}_{0}$ \\
\hline
\end{tabular}

Note: $\mathrm{L}_{0}$ and $\mathrm{L}_{\mathrm{L}}$ were 0 and $0.75 \mathrm{tha}^{-2}$ lime application. $\mathrm{Cd}_{0}$ and $\mathrm{Cd}_{6}$ were 0 and $6.0 \mathrm{mg} \mathrm{kg}{ }^{-1} \mathrm{Cd}$ treatment.

differential proteins identified, in which the expression of 10 proteins related to saponin synthesis was significantly different $(P<0.05)$, including $\mathrm{P} 450, \beta$-AS and glycosyl transferase (GT) based on GO and KEGG analysis (Table 4).

The expression of $\mathrm{P} 450$ reductase, $\beta$-AS, glycosyl transferase UGTPg34, and glycosyl transferase UDP84B1 were down-regulated under $0.75 \mathrm{t} \mathrm{ha}^{-2}$ lime application compared to non lime application (Table 4). The glycosyl transferase UDP84B1 protein homologous to the grape Vitis vinifera was down-regulated. The UGTPg19 protein homologous to ginseng was downregulated.

The expression of P450 (CYP72A129) protein homologous to Panax ginseng was down-regulated under $6.0 \mathrm{mg} \mathrm{kg}^{-1} \mathrm{Cd}$ treatment. The expression of P450 (CYP736A54) protein homologous to Bupleurum chinense was up-regulated. The expression of the glycosyl transferase UGTPg34 protein homologous to Panax ginseng was down-regulated.

When treated with $6.0 \mathrm{mg} \mathrm{kg}^{-1} \mathrm{Cd}+0.75 \mathrm{t} \mathrm{ha}^{-2}$ lime, the expression of P450 (CYP72A129 and CYP72A129like) proteins homologous to Panax ginseng was downregulated. The expression of P450 (CYP736A54) protein homologous to Bupleurum chinense was up-regulated. The expression of glycosyl transferase UGTPg19 and UGTPg34 protein homologous to Panax ginseng was down-regulated, and the expression of glycosyl transferase 84B1 protein was up-regulated.

\section{Discussion}

\section{Effects of Cd Stress on the Growth and Saponin Content in Roots of Panax notoginseng under Lime Application}

Soil $\mathrm{pH}$ is one of the most important factors affecting soil $\mathrm{Cd}$ formation and bioavailability. The change of $\mathrm{pH}$ has a great influence on the effective fraction of $\mathrm{Cd}$ in soil. The $\mathrm{OH}$-ion in $\mathrm{Ca}(\mathrm{OH})_{2}$, not only increases the $\mathrm{pH}$ value of the soil, but also promotes the formation of hydroxyl metal [35]. The hydroxyl metal ion has a strong affinity with the adsorption site of the soil and can be effectively adsorbed on the soil surface. The increase of $\mathrm{OH}^{-}$in the soil causes $\mathrm{Cd}^{2+}$ to combine with $\mathrm{CO}_{3}{ }^{2+}$ and $\mathrm{OH}^{-}$to form insoluble precipitates, which are fixed in the soil and reduce the effective $\mathrm{Cd}$ content in the soil $[36,37]$. The increase of $\mathrm{pH}$ will lead to the decrease of hydrogen ions and free metal cations, reduce the competition with $\mathrm{Cd}^{2+}$ on soil adsorption, facilitate the adsorption of $\mathrm{Cd}$ and soil surface, and reduce the content of available $\mathrm{Cd}$ in soil. However, the reduction of available $\mathrm{Cd}$ in the soil by lime depends on the form and dose of lime, especially in the case of high $\mathrm{Cd}$ content in the soil. Application of lime increases soil $\mathrm{pH}$ and reduces soil available $\mathrm{Cd}$ content. Correlation analysis showed that there was a significant negative correlation between the ratio of $\mathrm{Ca} / \mathrm{Cd}$ treatment concentration and soil available $\mathrm{Cd}$ content and $\mathrm{Cd}$ content of main root $(P<0.05)$. It is indicated that the concentration ratio of $\mathrm{Ca} / \mathrm{Cd}$ treatment be an important 
factor affecting the available $\mathrm{Cd}$ content in soil and the $\mathrm{Cd}$ content in the main root of $P$. notoginseng. With the increase of calcium ion concentration, the desorption of $\mathrm{Cd}$ increases, while the high concentration of $\mathrm{Cd}$ in soil solution can reduce the absorption and transport of calcium by roots, increase the absorption of $\mathrm{Cd}$, reduce the absorption of calcium by plants [38, 39].

Under the same lime application, the effect of cadmium stress on biomass, root length, root surface area and root volume of $P$. notoginseng had a dose effect. Correlation analysis showed that there were significant negative correlations between root length and soil effective $\mathrm{Cd}$ content $(P<0.05)$, main root $\mathrm{Cd}$ content $(P<0.01)$. Under certain cadmium stress, the application of lime can increase the biomass, root length, root surface area and root volume of roots to some extent. Ca plays an important role in reducing the absorption of $\mathrm{Cd}$ by plants and reducing the toxicity of $\mathrm{Cd}$ to plants $[38,40]$. Exogenous Ca treatment alleviated the DNA damage of Arabidopsis seedling root cells induced by $\mathrm{Cd}$ stress. Ca-binding protein is involved in the regulation of biological gene expression, DNA synthesis, repair and transcription to promote plant root growth[41]. Calcium not only acts as a plant's essential nutrient element, but more importantly, as a second intracellular signal transduction, initiates a series of physiological and biochemical processes and activates multiple resistance mechanisms in plants [42]. High concentrations of exogenous $\mathrm{Ca}$ treatment may increase solution concentration, cause osmotic stress and ionic toxicity, and may even aggravate $\mathrm{Cd}$ stress damage [31].

Under the same Cd stress, the saponin contents decreased with lime application. There may be competition between calcium and cadmium ions with lime application. With low $\mathrm{Cd}$ concentration treatments, the effect of lime on the synthesis of saponins was greater. With high $\mathrm{Cd}$ concentration treatments, the effect of $\mathrm{Cd}$ on the synthesis of saponin was dominant. There was a significant negative correlation between the content of saponins and $\mathrm{Cd}$ treatment concentration $(\mathrm{R}=-0.734$ and $-0.579, P<0.05, \mathrm{n}=6$, respectively, for 0.75 and $1.5 \mathrm{t} \mathrm{ha}^{-2}$ lime application treatments). Exogenous stress affects the synthesis of secondary metabolites by affecting the expression of key enzyme genes. For example, methyl jasmonate and ethyl jasmonate induced the expressions of SS and SE genes in $P$. notoginseng, and increased the accumulation of total saponins of $P$. notoginseng [37]. Liang et al (2011) found that high concentration B and Mn stress inhibited the expression of SS gene in key glycyrrhizic acid synthesis [43]. A certain concentration of $\mathrm{Zn}$ and Mo stress promoted the expression of SS gene. Zhu et al. (2017) showed a negative correlation between saponin content and soil Cd content in Paris polyphylla var. Yunnanensis [44]. Under treated with $30 \mathrm{mg} \mathrm{kg}^{-1}$ $\mathrm{Cd}$, notoginsenoside $\mathrm{R} 1$, ginsenoside $\mathrm{Rb} 1$, ginsenoside Rg1 and total saponins decreased [20]. The optimal application of lime may alleviate the toxicity of $\mathrm{Cd}$ stress to $P$. notoginseng.
The heterogeneity of ginsenoside Rg1, ginsenoside $\mathrm{Rb} 1$ and notoginsenoside R1 content was related to the balance of calcium and cadmium. Correlation analysis showed that there were significant negative correlations between $\mathrm{Rg} 1 / \mathrm{Rb} 1$ ratio and soil available $\mathrm{Cd}$ content $(P<0.05)$, Cd content of main root $(P<0.05)$. There was a significant negative quadratic correlation $(P<0.05)$ between the ratio of $\mathrm{Rg} 1 / \mathrm{Rb} 1$ and $\mathrm{Ca} / \mathrm{Cd}$ treatment, which was a signal-peak modal. It could be suggested that the conversion of the diol saponin Rbl to the triol saponin $\operatorname{Rg} 1$ is not only inhibited by cadmium, but also affected by the balance of calcium and cadmium. Under the ratio of $\mathrm{Ca} / \mathrm{Cd}$ treatment $<680$, the conversion of the diol saponin Rb1 to the triol saponin Rg1 was promoted. Under the ratio of $\mathrm{Ca} / \mathrm{Cd}$ treatment $>680$, the conversion might be inhibited. There was a significant logarithmic correlation between the $\mathrm{R} 1 /(\mathrm{Rg} 1+\mathrm{Rb} 1)$ ratio and the $\mathrm{Ca} /$ $\mathrm{Cd}$ treatment ratio $(P<0.05)$. Therefore, the higher the ratio of $\mathrm{Ca} / \mathrm{Cd}$ treatment was, the greater the ratio of the content of notoginsenoside R1 to the total saponin content was. The heterogeneity of saponin monomer was affected by the balance of calcium and cadmium. The inhibition of saponin synthesis by cadmium and calcium occurred at different stages of metabolism. The inhibitory effect of cadmium on the conversion process of glycolic saponins to triol saponins was more prominent.

\section{Enzymology and Proteomics Mechanisms of the Metabolism of Saponin under Cd Stress with Lime Application}

Saponin is a dammarane-type tetracyclic triterpene whose synthesis pathway includes the mevalonate pathway and the 2C-methyl-4-phosphate-4D-erythritol pathway $[45,46]$. The mevalonate pathway is dominant, which is co-catalyzed by a number of enzymes. Mevalonate is catalyzed by three consecutive ATPdependent enzymes (mevalonate kinase (MVK), phosphomevalonate and mevalonate pyrophosphate decarboxylase) to form isopentenyl pyrophosphate [21], Isopentenyl pyrophosphate ultimately produces triterpenoid saponins by catalysis and modification of a series of enzymes. Mevalonate kinase is one of the rate-limiting enzymes in the mevalonate pathway. It is present in the cytoplasm and has a highly conserved domain. It has two conserved regions that bind to the substrate and ATP, and undergoes catalytic reaction. MVK is the first ATP-dependent enzyme [47, 48]. The activity of mevalonate kinase increased under $0.6 \mathrm{mg} \mathrm{kg}-1 \mathrm{Cd}$ treatment. The activity of mevalonate kinase decreased with the increase in $\mathrm{Cd}$ treatment concentrations, indicating the dose effect. This result was similar to founds of Zhu et al. (2014) [20]. It may be due to the low concentration of $\mathrm{Cd}$ initiating its own defense system. The mevalonate kinase activity was inhibited under $0.75 \mathrm{t} \mathrm{ha}^{-2}$ lime application. Under the same $\mathrm{Cd}$ treatment, the activity of mevalonate 
kinase gradually decreased with the increase in lime application levels. The inhibitory effect of $\mathrm{Ca}$ and $\mathrm{Cd}$ on mevalonate kinase activity may be due to an ATPdependent enzyme of MVK. Calcium and Cadmium reduced the absorption of phosphorus by plants, inhibited the energy metabolism of plants and the supply of ATP. The ions $\mathrm{Ca}^{2+}, \mathrm{Mg}^{2+}, \mathrm{Al}^{3+}$, and $\mathrm{Fe}^{3+}$ in the soil were susceptible to chemical precipitation with phosphate, which caused most of the soil phosphorus to be converted into insoluble fractions, reduced the absorption and utilization of phosphorus by plants [49,50].

$\mathrm{SS}$ is a key enzyme in the synthesis of saponins. There were significant positive correlations $(P<0.05)$ between SS activity and R1 content, Rg1 content. Under the application of lime, the SS activity in the main root was increased to some extent, which suggested that $\mathrm{SS}$ activity be promoted by $\mathrm{Ca}$. Cd stress decreased SS enzyme activity. There were significant negative correlations $(P<0.05)$ between SS activity, soil effective $\mathrm{Cd}$ content, and $\mathrm{Cd}$ content of main root.

In the catalytic process, cytochrome $\mathrm{P} 450$ reductase combines with heme to form a thiol-ferrous-carbon monoxide complex. The complex has the largest characteristic absorption spectrum at $450 \mathrm{~nm}$, which is dependent on Heme, a family of multifunctional metal-containing enzymes that catalyze a variety of complex oxidation reactions [51]. Cytochrome P450 (Cytochrome $\mathrm{P} 450$ ) catalyzes the hydroxylation and oxidation of the triterpene skeleton [52]. Cytochrome $\mathrm{P} 450$ is a type of oxidase encoded by a supergene family. Their expression products are similar and their substrates are different. It requires multiple cytochrome P450s to participate in the synthesis of the final product. In the case of same the amount of lime applied, the $\mathrm{P} 450$ reductase activity decreased with increase in $\mathrm{Cd}$ treatment concentrations. There were significant negative correlations between $\mathrm{P} 450$ reductase activity and soil available $\mathrm{Cd}$ content $(P<0.01), \mathrm{Cd}$ content of main root $(P<0.05)$. The expression of $\mathrm{P} 450$ gene of $P$. notoginseng under the exogenous $\mathrm{Cd}$ stress upregulated at the low concentration, down-regulated at concentration.Under the exogenous Cd stress, P450 gene expression did not show significant correlation with saponins R1, ginsenoside Rb1, ginsenoside Rg1 and total saponins. In this study, P450 (CYP72A129) protein homologous to Panax ginseng was down-regulated when treated with $6.0 \mathrm{mg} \mathrm{kg}^{-1} \mathrm{Cd}^{2+}$. The expression of P450 (CYP736A54) protein homologous to Bupleurum chinense was up-regulated. It suggested that different P450 isoenzyme activities and expression levels have different responses to Cd stress. Saponin synthesis and metabolism could not be indicated by only one gene express of $\mathrm{P} 450$.

Under the same $\mathrm{Cd}$ treatment concentration, the inhibitory effect of cadmium on cytochrome P450 was alleviated with $0.75 \mathrm{t} \mathrm{ha}^{-2}$ lime application at low $\mathrm{Cd}$ treatment concentrations. There was a significant quadratic correlation between $\mathrm{P} 450$ reductase activity and $\mathrm{Ca} / \mathrm{Cd}$ treatment ratio $(P<0.05)$, which was a single-peak model. Under the ratio of $\mathrm{Ca} / \mathrm{Cd}$ treatment 696, the activity of $\mathrm{P} 450$ reductase was the highest. It suggested that the balance of $\mathrm{Ca} / \mathrm{Cd}$ be important for the activity of $\mathrm{P} 450$ reductase. Under 0.75 and $1.5 \mathrm{t} \mathrm{ha}^{-2}$ lime application, there were significant positive correlations between the saponins content of main root and $\mathrm{P} 450$ reductase activity, $\mathrm{P} 450$ reductase activity and $\mathrm{R} 1$ content, ratio of $\mathrm{R} 1 /(\mathrm{Rg} 1+\mathrm{Rb} 1) \quad(P<0.05)$. Under $6.0 \mathrm{mg} \mathrm{kg}^{-1} \mathrm{Cd}^{2+}+0.75 \mathrm{t} \mathrm{ha}^{-2}$ lime application treatment, protein expressions of P450 (CYP72A129 and CYP72A129-like) homologous to Panax ginseng was down-regulated. The protein expression of $\mathrm{P} 450$ (CYP736A54) homologous to Bupleurum chinense was up-regulated. In the presence of calcium, the difference in response of $\mathrm{P} 450$ isoenzymes was the similar as under $\mathrm{Cd}$ treatment. Therefore, the decrease in the content of saponins might be related to the decrease of $\mathrm{P} 450$ reductase activity and the down-regulation of P450CYP72A129 protein expression. The P450 reductase was involved in the synthesis of triol type saponin, inhibiting the conversion of diol type saponin to triol type saponin. Since P450 contains $\mathrm{Fe}^{2+}$ ions, the inhibitory effect of cadmium and calcium on $\mathrm{P} 450$ activity may be related to decrease in uptake of $\mathrm{Fe}^{2+}$ due to cadmium and calcium replacing $\mathrm{Fe}^{2+}$ at the active site, resulting in a decrease in P450 activity. Because of changing the $\mathrm{pH}$ with lime application, the availability of iron in the soil decreased, limiting the absorption of iron from the soil by plants [53].

In the saponin synthesis pathway, the cyclization of 2,3-oxidosqualene is catalyzed by oxidosqualene cyclases (OSC) [54]. The $\beta$-AS belongs to the OSC superfamily, which catalyzes the cyclization of 2,3-oxidized squalene to $\beta$-aromatic alcohol and promotes the reaction into the triterpenoid synthesis tributary [55]. There were significant positive correlations between $\beta$-AS activity and R1 content $(P<0.01), \mathrm{R} 1 /(\mathrm{Rg} 1+\mathrm{Rb} 1)$ ratio $(P<0.05)$. The activities of $\beta$-AS decreased with increase in $0-6.0 \mathrm{mg} \mathrm{kg}^{-1} \mathrm{Cd}^{2+}$ treatment concentrations. Under the same $\mathrm{Cd}$ treatment concentration, the $\beta$-AS activity decreases with increase in lime application levels. The activities of $\beta$-AS was inhibited and it protein expression was down-regulated with the lime application. The activities of $\beta$-AS similar to $\mathrm{P} 450$ reductase, participates in the synthesis of triol saponin. The activities of $\beta$-AS and the synthesis of triol saponin were inhibited by both lime and $\mathrm{Cd}$ treatments. The decrease in the content of notoginsenoside might be related to the decreased activities of $\mathrm{P} 450$ reductase and $\beta$-AS.

The synthesis of triterpenoid saponins is accomplished by adding a glycosyl group to the saponin by glycosyl transferase (GT) [56]. UGTs are a subfamily of GTs whose main function is to be responsible for the glycosylation of saponins. The triterpenoid compound forms a sugar chain by glycosylation of a glycosyltransferase at positions C3, $\mathrm{C} 16$, C28, to produce saponin. Sugar chain donors 
include UDP-glucose, UDP-rhamnose, UDP-galactose, UDP-xylose, and UDP-arabinose [4, 57, 58]. When Cd was treated and lime was applied, UGTPg34 was down-regulated. The expression of glycosyltransferases UGTPg19 and UGTPg34, which are homologous to $P$. ginseng, was down-regulated, and the expression of glycosyltransferase 84B1 was up-regulated under $\mathrm{Cd}$ treatments. The expression of the glycosyl transferase GTs was down-regulated due to both $\mathrm{Cd}$ and lime treatments, which affected the saponin content. Because $\mathrm{Cd}^{2+}$ might be bound to the active site-thiol group and the imidazole-containing ligand in the enzyme molecule to form a stable complex, thereby competing with the substrate and inhibiting the enzyme activity.

Therefore, although calcium promoted SS activity, excessive cadmium and calcium led to decrease in the activities of mevalonate kinase, P450 reductase, $\beta$-fragrant alcohol synthase and glycosyltransferase and their protein expression in the saponin synthesis pathway. The $\mathrm{Ca} / \mathrm{Cd}$ ratio met a single-peak model with the conversion of the diolic saponin to the triol saponin. The effects of cadmium/lime on saponin synthesis by the expression and activity of key enzymes in the upstream MEP/DOXP pathway (terpenoid backbone biosynthesis)should be paid more attention in the further research.

\section{Conclusion}

With the increased in lime application levels under $\mathrm{Cd}$ stress, the soil available $\mathrm{Cd}$ content and the $\mathrm{Cd}$ content in the main root of $P$. notoginseng significantly reduced, the biomass and root length of the main root of $P$. notoginseng increased. The content of saponins decreased with the activities and expressions of mevalonate kinase (MVK), P450 reductase and $\beta$-AS decreased. When the $\mathrm{Ca} / \mathrm{Cd}$ ratio less than 680, the synthesis of triol type saponin and P450 activity were promoted with the application of lime. It is recommended the lime application rate should be less than 0.948 and $4.59 \mathrm{t} \mathrm{ha}^{-2}$ lime under 0.6 and $3.0 \mathrm{mg} \mathrm{kg}^{-1} \mathrm{Cd}$ treatments, respectively, based on quadratic correlation between the ratio of $\mathrm{Rg} 1 / \mathrm{Rb} 1$ and the $\mathrm{Ca} / \mathrm{Cd}$ treatment ratio. The results indicate that excessive application of calcium or cadmium stress might inhibit the conversion of glycol type to triol type saponin and glycosylation, change the heterogeneity of saponin monomer, and reduce the total amount of saponin.

\section{Acknowledgements}

The authors would like to thank to The National Natural Science Foundation of China (Grant Nos. 31560163 and 41867055) and The Yunnan Key Research and Development Project (2019BC001-04).

\section{Conflict of Interest}

The authors declare no conflict of interest.

\section{References}

1. YANG H.F., WANG Y.B., LI J.L. Impacts of $\mathrm{Cu}$ and $\mathrm{Zn}$ pollution on rape (Brassica chinensis L.) growth and accumulation effect of heavy metals in paddy soil. Ecol. Environ. Sci., 20 (10), 1470, 2011.

2. WEI B.G., YANG L.S. A review of heavy metal contaminations in urban soils, urban road dusts and agricultural soils from China. Microchem. J., 94 (2), 99, 2010.

3. XUE L., LIU J.F., SI S.Q., WEI Y., CHANG E.M., GAO M., JIANG Z.P. A review on the progress of proteomic study on plant responses to heavy metals. Acta Prataculturae Sin., 22 (4), 300, 2013.

4. ZHANG R.R., ZHANG P., DU S.T. Oxidative stress related signals and their regulation under Cd stress: A review. Chin. J. Appl. Ecol., 27 (3), 981, 2016.

5. HUANG B.F., XIN J.L. Mechanisms of heavy metal accumulation in plants: a review. Acta Pratacu. Sin., 22 (1), $300,2013$.

6. WANG X.H., DAI L. Physiology and biochemical mechanism of the cadmium in crop roots. Sci. Agric. Sin., 49 (22), 4323, 2016.

7. PEREZ-CHACA M.V., RODRÍGUEZ-SERRANO M., MOLINA A.S., PEDRANZANI H.E., ZIRULNIK F., SANDALIO L.M., ROMERO-PUERTAS M.C. Cadmium induces two waves of reactive oxygen species in Glycine $\max (\mathrm{L})$ roots. Plant Cell Environ., 37, 1672, 2014.

8. PITERKOV J., LUHOV L., NAVTILOV B., SEDLÁŘOVÁ M., PETŘIVALSKÝ M. Early and long-term responses of cucumber cells to high cadmium concentration are modulated by nitric oxide and reactive oxygen species. Acta Physio. Plant., 37, 1-12, 19, 2015.

9. XIE H.L., LIU J., CHEN S., WANG J.Y.,FU W., LI Y.P., WANG H., XIAO Q.T., ZHENG X.Y.., HUANG J.W., LIN R.Y., LIN W.X. Analysis of differentially expressed proteins in Perilla frutescens (L.) Britt. leaves under cadmium stress. Chin. J. Ecol-Agric., 22 (10), 1207, 2014.

10. ROTH U., VON ROEPENACK-LAHAYE E., CLEMENS S. Proteome changes in Arabidopsis thaliana roots upon exposure to $\mathrm{Cd}^{2+}$. J. Exp. Bot., 57 (15), 4003, 2006.

11. KIEFFER P., DOMMES J., HOFFMANN L., HAUSMAN J.F., RENAUT J. Quantitative changes in protein expression of cadmium-exposed poplar plant. Proteomics., 8, 2514, 2008.

12. DOHERTY M.K., WHITFIELD P.D. Proteomics moves from expression to turnover: update and future perspective. Expert. Rev. Proteomics., 8 (3), 325, 2011.

13. LI Z.D., ZHAO R.H., ZHANG Z.C., YU J., GU W., HE S., CAO G.H. Advances in biosynthesis and regulation mechanism of notoginseng saponins. Chin. J. Exp. Tradi. Med. Formulae., 24 (14), 71, 2018.

14. ZHANG W.B., TAO S.G., ZENG H.C., ZHOU J.M. HPLC determination of Xuesaitong capsules ginsenoside Rg1, $\mathrm{Rb} 1$ and the content of notoginsenoside R1. Spec. Wild Econ. Animal Plant Res., 4, 49, 2010.

15. SHI L., GE F., LIU D.Q., CHEN C.Y. Advances on biosynthesis of Panax notoginseng saponins and regulation of key enzymes. Acta Bot. Boreali-Occidentalia Sin., 30 (11), 2358, 2010 
16. ZU Y.Q.,MEI X.Y., MIN Q., SU Y., MA N., FENG G.Q., LI Y. Effects of As stress on contents of saponin and flavonoid, key enzymes activities of Panax notoginseng and its proteomic analysis. Chin. J. Appl. Ecol., 27 (12), 4013, 2016

17. ZHU H.,TENG Y., ZHANG M.Y., MA W.T., LIU W.X., REN W.J., LUO Y.M., LI Z.G., GUO D. Pollutant accumulation and microbiological characteristics change in notoginseng-planting soils. Soils, 47 (1), 121, 2015.

18. ZU Y.Q., CHENG S.C., KE H.L., GUO X.H., WU J., LI Y. Distribution of $\mathrm{Pb}, \mathrm{Cd}, \mathrm{Cu}$ and $\mathrm{Zn}$ in plant of Panax notoginseng and soil in Wenshan Prefecture, a Panax notoginseng growing region. J. Ecol. Rural. Environ., 33 (4), 317, 2017.

19. ZHANG Y.C., SONG F.R., LIU Z.Q.,WANG S.M., HOU Y.B., WU C. Effect of treating ginseng seeds with plasma ray radiation/magnetization on content of ginsenosides. Chin. J. Appl. Chem., 3, 311, 2009.

20. ZHU M.L., CHEN Z.J., JIANG Y., WEI F.G., CUI B., JIANG T.X., CAI H.B., ZHANG W.S. Cadmium stress of soil on cadmium enrichment in different tissues and its main active compositions of Panax notoginseng. Chin. Tradit. Patent Med., 36 (2), 342, 2014.

21. GUO X., LUO H.M., CHEN S.L. Cloning and analysis of mevalonate kinase (PnMVK1) gene in Panax notoginseng. Acta Pharm. Sin., 47 (8), 1092, 2012.

22. CHEN S.J., PAN W.J., MEN Y.S., ZONG X.F., WANG S.G. Effects of acid soils treated with lime and polyacrylamide on the growth and physiological characteristics of fluecured tobacco. Plant Nutr. Fert. Sci., 18 (5), 1243, 2012.

23. POOVAIAH B.W. Biochemical and molecular aspects of calcium action. Acta Hortic., 326, 139, 1993.

24. SCHÖNKNECHT G.Calcium signals from the vacuole. Plants, 2, 589, 2013.

25. NOMURAA H., SHIINA T. Calcium signaling in plant endosymbiotic organelles: mechanism and role in physiology. Mol. Plant., 7, 1094, 2014.

26. ZHENG Y., CHEN Z.J. Organellar calcium signaling in plants. Plant Physiol. Commun., 51 (8), 1195, 2015.

27. GIACOMELLO M., DRAGO I., PIZZO P., POZZAN T. Mitochondrial $\mathrm{Ca}^{2+}$ as a key regulator of cell life and death. Cell Death Differ., 14, 1267, 2007.

28. SEIGNEURIN BERNY D., GRAVOT A., AUROY P., MAZARD C., KRAUT A., FINAZZI G., GRUNWALD D., RAPPAPORT F., VAVASSEUR A., JOYARD J., RICHAUD P., ROLLAND N. HMA1, a new Cu-ATPase of the chloroplast envelope, is essential for growth under adverse light conditions. J. Biol. Chem., 281, 2882, 2006.

29. LIN L.L., SHEN L., LIN Y.Z., ZHONG F.L., YE L.P., QU X.L. The role of calcium-signal in plant adaptation to abiotic stress. Chin. Hortic. Abstract., 4, 41, 2015.

30. SI L., GUO C.H., LIANG F., PENG C., XIAO X.Y., FENG W.L. Effects of lime and water management on uptake and translocation of cadmium in rice. Transactions Chin. Soc. Agric. Eng., 33 (24), 111, 2017.

31. WAN C.Y., WANG Y.T., ZENG W.L., LI S.S. Alleviation of $\mathrm{Cd}$ Toxicity in Arabidopsis thaliana Seedlings by Exogenous $\mathrm{Ca}^{2+}$ or $\mathrm{K}^{+}$. Chin. Bull. Bot., 49 (3), 262, 2014.

32. WISNIEWSKI J.R., ZOUGMAN A., NAGARAJ N., MANN M. Universal sample preparation method for proteome analysis. Nature methods, 6, 359, 2009.

33. ROSS P.L., HUANG Y. N., MARCHESE J.N., WILLIAMSON B., PARKER K., HATTAN S. Multiplexed protein quantitation in Saccharomyces cerevisiae using amine-reactive isobaric tagging reagents. Mol. Cell. Proteom., 3, 1154, 2004.
34. SZKLARCZYK D., MORRIS J.H., COOK H., KUHN M., WYDER S., SIMONOVIC M. The STRING database in 2017: quality-controlled protein-protein association networks, made broadly accessible. Nucleic Acids Res., 45, 362, 2017.

35. LI P., WANG X.Q., LANG M., ZHANG T.L. Effects of amendments on the fraction transform of heavy metals in soil contaminated by copper and cadmium. Chin. Environ. Sci., 32 (7), 1241, 2012.

36. ZHOU X.Y., FENG W.Q., QIN Y.S., YU H., LIAO M.L., LIU Y.C., WANG C.Q., TU S.H. Effect of magnesium, manganese, activated carbon and lime on soil $\mathrm{pH}$ and available cadmium. J. Soil Water Conserv., 26 (6), 199, 208, 2012.

37. HU F., ZHONG J. Jasmonic acid mediates gene transcription of ginsenoside biosynthesis in cell cultures of Panax notoginseng treated with chemically synthesized 2-hydroxyethyl jasmonate. Process Biochem., 43 (1), 113, 2008.

38. SONG Z.G., XU M.G., LI J.M., JU X.H., TANG S.R. Effects of calcium on cadmium bioavailability in lateritic red soil and related mechanisms. Chin. J. Appl. Ecol., 20, $1705,2009$.

39. VOEGELIN A., VULAVA V.N. Reaction-base model describing competitive sorption and transport of $\mathrm{Cd}, \mathrm{Zn}$, and Ni in acidic soil. Environ. Sci. Technol., 35, 1651, 2001.

40. ABD-ALLAH E.F., HASHEM A., ALQARAWI A.A., WIRTH S., EGAMBERDIEVA D. Calcium application enhances growth and alleviates the damaging effects induced by $\mathrm{Cd}$ stress in sesame (Sesamum indicum L.). J. Plant Interact., 12 (1), 237, 2017.

41. WANG C.Q., WANG B.S. $\mathrm{Ca}^{2+}$-calmodulin is involved in betacyanin accumulation induced by dark in $\mathrm{C} 3$ halophyte Suaeda salsa. J. Integr. Plant Biol., 49, 1378, 2007.

42. CHEN G.L., JIA K.Z. Effects of calcium and calmodulin antagonist on antioxidant systems of eggplant seedlings under high temperature stress. Sci. Agric. Sin., 38, 197, 2005.

43. LIANG X.H., LUAN W.J., LIANG J., ZHANG F.X. RT -PCR Analysis on the differential expression of the key enzyme genes involved in glycyrrhizic acid synthetic metabolic pathway under $\mathrm{B}, \mathrm{Mn}, \mathrm{Zn}$ and Mo elements treatment. Lishizhen Med. Mater. Med. Res., 22 (10), 2351, 2011.

44. ZHU Y.X., HUANG Y.F., KE F. Study on correlation between content of polyphyllins and heavy metals in Paris Polyphylla var. Yunnanensis.Eval. Anal. Drug-Use Hosp. Chin., 17 (10), 1315, 2017.

45. SUN Y., ZHAO H.W., GE F., SHI L., LIU D.Q. The construction of over-expression vector for Panax notoginseng SS gene and its transformation. Acta Pharm. Sin., 48 (1), 138, 2013.

46. ZU Y.Q., LI Z.R., MEI X.Y., WU J., CHENG S.C., JIANG Y.Q., LI Y. Transcriptome analysis of main roots of Panax notoginseng identifies genes involved in saponin biosynthesis under arsenic stress. Plant Gene, 16, 1, 2018.

47. WANG M.L., FAN Q.J., LI Y.B.,QU Z.C., CUI X.S. Research progress on mevalonate kinase genes. J. Agric. Sci. Technol., 13 (3), 17, 2011.

48. WANG P.J., CHEN D., CAO H.L., YAO X.Q., CHEN D., YANG G.Y., ZHENG Z.L., YE N.X. Cloning and expression of mevalonate kinase geneCs $M V K$ in tea plant. J. Southern Agric., 48 (10), 1741, 2017.

49. HEDLEY M., MCLAUGHLIN M. Reactions of phosphate fertilizers and by-products in soils.In Phosphorus: 
Agriculture and the Environment. Editor Sims J.T., Sharpley A.N., Willey, USA, 46, 181, 2008.

50. GAO Y.J., KANG L.F., CHU G.X. Polymerization degree and rate of polyphosphate fertilizer affected the availability of phosphorus, Fe, $\mathrm{Mn}$ and $\mathrm{Zn}$ in calcareous soil. J. Plant Nutr. Fert., 24 (5), 1294, 2018.

51. PAN L.X., ZHU J., WANG Q.Y., YANG D.F. Cytochromes P450 for the antibiotic biosynthesis in Streptomyces. Chin. J. Antibiotics., 44 (2), 153, 2019.

52. XU J.S., WEI J.H., TAO Y.W., SUN J., SUI C. Advances in studies on functions of plant cytochrome P450 in triterpenoid saponin biosynthesis. Chin. Tradit. Herbal. Drugs., 43 (8), 1635, 2012.

53. LIU L.J., ZHANG X.M., SU Z.M., YI Y. Physiological and biochemical characteristics of plant iron nutrition in calcareous soil: research progress. Chin. Agric. Sci. Bull., 34 (11), 6, 2018.

54. LONG Y.H., LI F.F., YANG G., XIN C.B. Gene cloning and expression level of $\beta$-AS and their correlation with content of saponins in Eleutherococcus senticosus. Chin. Tradit. Herbal. Drugs., 46 (9), 1354, 2015.
55. JIN M.L., LEE D.Y., UM Y., LEE J.H., PARK C.G. Isolation and characterization of an oxidosqualene cyclase gene encoding a beta-amyrin synthase involved in Polygala tenuifolia Willd. saponin biosynthesis. Plant Cell Rep., 33 (3), 511, 2014.

56. AUGUSTIN J.M., DROK S., SHINODA T., SANMIYA K., NIELSEN J.K., KHAKIMOV B., OLSEN C.E., HANSEN E.H., KUZINA V., EKSTRØM C.T., HAUSER T., BAK S. UDP-glycosyltransferases from the UGT3C subfamily in Barbarea vulgaris catalyze sapogenin 3-O-glucosylation in saponin-mediated insect resistance. Plant Physiol., 160 (4), 1881, 2012.

57. ZHANG Y.X., JIN L., FENG S.S., LIU J.G., CAI T.Y. Effects of Cd on activity and gene expression of antioxidant enzymes in hyperaccumulator Solanum nigrum. J. Graduate. Univ. Chin. Acad. Sci., 30 (1), 11, 2013.

58. ZHU M.L., ZENG X.C., JIANG Y.X., FAN X.T., CHAO S.H., CAO H.B., ZHANG W.S. Effect on the expression of key enzymes DS and P450 genes in the medicinal composition synthesis of Panax notoginseng under cadmium stress. Chin. Tradit. Herbal. Drugs., 47 (24), 4428, 2016. 